ISSN 0258-7122

Bangladesh J. Agril. Res. 36(2) : 319-331, June 2011

\title{
EFFECTS OF TEXTILE INDUSTRIAL WASTE WATER AND UPTAKE OF NUTRIENTS ON THE YIELD OF RICE
}

\author{
R. A. BEGUM ${ }^{1}$, M. W. ZAMAN ${ }^{2}$, A. T. M. A. I. MONDOL ${ }^{3}$ \\ M. S. ISLAM ${ }^{4}$ AND K. M. F. HOSSAIN ${ }^{5}$
}

\begin{abstract}
An experiment was conducted at Mouchack textile industrial area of Gazipur for two consecutive years (1999-2000) to study the effects of use of industrial waste water on the yield, nutrient content, and uptake of Boro rice. The experiment was laid out in a randomized complete block design (RCBD) with three replications. The six treatments in this study were: $\mathrm{T}_{1}$ : uncontaminated field + fresh water, $\mathrm{T}_{2}$ : uncontaminated field + mixed water, $\mathrm{T}_{3}$ : uncontaminated field + contaminated water for non-contaminated field, and $\mathrm{T}_{4}$ : effluent contaminated field + fresh water, $\mathrm{T}_{5}$ : effluent contaminated field + mixed water, $\mathrm{T}_{6}$ : effluent contaminated field + contaminated water for contaminated field. Among the six treatments, uncontaminated field + fresh water $\left(T_{1}\right)$ showed the best positive effect on rice. The N, P. K, and $\mathrm{S}$ contents and uptake were higher in $\mathrm{T}_{1}$, but $\mathrm{Zn}$, $\mathrm{Mn}, \mathrm{Fe}, \mathrm{Cu}$, and $\mathrm{Pb}$ were higher in $\mathrm{T}_{6}$ treatment. The treatment $\mathrm{T}_{1}$, gave the highest grain yield (5.23 t/ha in 1999 and 5.40 t/ha in 2000), followed by mixed water (4.19 t/ha in 1999 and $4.24 \mathrm{t} / \mathrm{ha}$ in 2000) in both the growing seasons.
\end{abstract}

Keywords: Industrial waste water, heavy metal, textile waste water, yield, nutrient content, uptake and rice.

\section{Introduction}

In Bangladesh, industrial wastes and effluents are being discharged at random without treatments directly to soil, canals, and rivers. The solid wastes are also used in land filling. They pollute our soils and natural water systems as well as ground water endangering human health, aquatic lives, and crop production in Bangladesh. They contain heavy metals like $\mathrm{Cu}, \mathrm{Zn}, \mathrm{Pb}, \mathrm{Cr}, \mathrm{Cd}, \mathrm{As}, \mathrm{Hg}, \mathrm{Mn}$, and $\mathrm{Fe}$. Some of them are toxic to plants and some others to both plants and animals. In areas where irrigation water is scarce, the use of industrial wastewater is an important source for supplementing water resources. Furthermore, reuse may help alleviate industrial disposal problems by reducing the volume of industrial wastewater involved. The uptake of heavy metals by plants from contaminated soils is of great concern because an excess of dietary intake of some of these heavy metals (e.g. $\mathrm{Pb}$ and $\mathrm{Cd}$ ) might be hazardous to consumers. These metals

${ }^{1}$ Principal Scientific Officer, Soil Science Division, Bangladesh Agricultural Research Institute (BARI), Gazipur, ${ }^{2}$ Professor, Deptt. of Agril. Chemistry, Bangladesh Agricultural University (BAU), Mymensingh, ${ }^{3}$ Senior Scientific Officer and ${ }^{4}$ Senitific Officer, Soil Science Division, BARI, Gazipur, ${ }^{5}$ Scientific Officer, Agronomy Division, BARI, Gazipur, Bangladesh. 
even in trace amounts destroy enzymes of living cells and hence their discharge into the environment must be carefully controlled and minimized. This in turn, directly or indirectly, it is affecting the soil and crop productivity and quality of agricultural products because $\mathrm{Cd}$, $\mathrm{As}, \mathrm{Cr}$, and $\mathrm{Hg}$ are extremely poisonous (Hellawell, 1986). Their uptake and accumulation in plant have been known to result in negative effects on plant growth (Breekle and Kahle, 1992). The nature and extent of damage caused by industrial effluents are very alarming. Farmers of different industrial areas of Bangladesh cultivate rice around vicinity of different industries, which discharge effluents directly to the rice field. A systematic research work has not yet been done on soil in the industrial areas and its impact on crop production. Considering the above points, this study was undertaken to evaluate the effects of the use of industrial waste water on the yield and nutrient content of rice.

\section{Materials and Method}

A field experiment was conducted in Mouchak industrial area (under Madhupur soil tract) during Boro rice seasons of 1999 and 2000. The soil and crop of these areas are affected by the industrial effluents. Six treatment combinations in the study are as follows: $\mathrm{T}_{1}$ : uncontaminated field + fresh water, $\mathrm{T}_{2}$ : uncontaminated field + mixed waste, $\mathrm{T}_{3}$ : uncontaminated field + contaminated water for noncontaminated field, and $\mathrm{T}_{4}$ : effluent contaminated field + fresh water, $\mathrm{T}_{5}$ : effluent contaminated field + mixed water, $\mathrm{T}_{6}$ : effluent contaminated field + contaminated water for contaminated field. The experiment was laid out in RCBD with three replications with unit plot size $8 \mathrm{~m} \times 5 \mathrm{~m}$. During the boro season, 35 days old rice seedlings of BRRIdhan 29 were transplanted on 29 January 1999 and 24 January 2000 in lines with $20 \times 20 \mathrm{~cm}$ plant spacing. The fertilizer doses were $\mathrm{N}_{120} \mathrm{P}_{90} \mathrm{~K}_{60}$ and $\mathrm{S}_{20} \mathrm{~kg} / \mathrm{ha}$. Half of the nitrogen was used during final land preparation and the remaining half was applied in two equal splits at 55 and 85 days after transplanting. At physiological maturity, the crop was harvested on 22 May 1999 and 20 May 2000. Fresh water was collected from the shallow tube well installed around the rice field. The fresh water was mixed with the industrial effluent collected from near by industries by the bucket and then mixed with shallow tube well water at I : I ratio. The chemical characteristics of polluted soils from Mouchack area are presented in Table 1. During the growing period, soil and crop parameters were measured. Soil samples were also collected at different intervals for measuring soil physical and chemical properties. Plant samples were collected at different stages of growth to measure the heavy metal concentrations. The roots were collected after harvesting of rice. Plant root and rice grain samples were analyzed by using standard methods. Data were collected on yield and yield contributing characters and statistically analyzed following F-test and the mean separation was done following DMRT (Steel and Torii, 1960). 
Table 1. Chemical constituents of soil samples from industrial areas of Mouchack (Composite of 10 samples).

\begin{tabular}{|c|c|c|c|c|c|c|c|c|c|c|c|c|c|c|c|c|c|}
\hline Sample & $\mathrm{pH}$ & $\begin{array}{l}\mathrm{OM} \\
(\%)\end{array}$ & $\begin{array}{c}\text { Total } \\
\mathrm{N} \\
(\%)\end{array}$ & $\begin{array}{c}\text { Avail- } \\
\text { able } \\
\text { P } \\
(\mathrm{mg} / \\
\mathrm{kg})\end{array}$ & $\begin{array}{c}\text { Total } \\
\mathrm{K} \\
(\mathrm{me} / \\
100 \mathrm{~g})\end{array}$ & $\begin{array}{l}\text { Total } \\
\mathrm{Na} \\
(\mathrm{me} / \\
100 \mathrm{~g})\end{array}$ & $\begin{array}{c}\text { Available } \\
\text { Mg } \\
(\mathrm{me} / \\
100 \mathrm{~g})\end{array}$ & $\begin{array}{c}\text { Available } \\
\mathrm{S} \\
(\mathrm{mg} / \mathrm{kg})\end{array}$ & $\begin{array}{c}\text { Available } \\
\text { Zn } \\
(\mathrm{mg} / \mathrm{kg})\end{array}$ & $\begin{array}{c}\text { Available } \\
\mathrm{Fe} \\
(\mathrm{mg} / \mathrm{kg})\end{array}$ & $\begin{array}{c}\text { Available } \\
\mathrm{Cu} \\
(\mathrm{mg} / \mathrm{kg})\end{array}$ & $\begin{array}{c}\text { Total } \\
\mathrm{Mn} \\
(\mathrm{mg} / \\
\mathrm{kg})\end{array}$ & $\begin{array}{c}\text { Total } \\
\text { As } \\
(\mathrm{mg} / \\
\mathrm{kg})\end{array}$ & $\begin{array}{c}\text { Total } \\
\mathrm{Pb} \\
(\mathrm{mg} / \\
\mathrm{kg})\end{array}$ & $\begin{array}{l}\text { Total } \\
\text { Co } \\
(\mathrm{mg} / \\
\mathrm{kg})\end{array}$ & $\begin{array}{c}\text { Total } \\
\mathrm{Ni} \\
(\mathrm{mg} / \\
\mathrm{kg})\end{array}$ & $\begin{array}{l}\text { Total } \\
\mathrm{Cd} \\
(\mathrm{mg} / \\
\mathrm{kg})\end{array}$ \\
\hline $\begin{array}{l}\text { Effluent } \\
\text { contaminated } \\
\text { soil }\end{array}$ & 6.55 & 1.61 & 0.26 & 27 & 2.47 & 5.73 & 5.66 & 74 & 80 & 109.82 & 191 & 189 & 19.4 & 74 & 89 & 92 & 2.6 \\
\hline Fresh water & 7.56 & - & 0.002 & 0.28 & 9.43 & 39.38 & 29.04 & 2.13 & 3.01 & 109.82 & 191 & 189 & 19.4 & 74 & 89 & 92 & 2.6 \\
\hline
\end{tabular}




\section{Results and Discussion}

\section{Effect of waste water}

Textile industrial waste water had significant effect on plant height and effective tillers per hill1 of Boro rice (Table 2). In uncontaminated field, the highest plant height, effective tillers per hill and panicle length were obtained with fresh water irrigation followed by mixed water irrigation in both the years. The lowest plant height and effective tillers per hill were observed with polluted water irrigation. Similarly, in effluent contaminated soil, the highest plant height and effective tillers per hill were noted when fresh water was used followed by mixed water. Fresh water irrigation gave the tallest plants because it contained considerable amount of macro and micro- nutrients and contained heavy metals within permissible limit. Adequate nutrients supply and presence of heavy metals within permissible limit in irrigation water enhanced root and shoot growth and thereby resulted the highest plant height, and tillers per hill.

Table 2. Effects of waste water of textile industries on plant height and effective tillers/hill1 of rice (BRRIdhan 29).

\begin{tabular}{l|l|c|c|c|c}
\hline \multirow{2}{*}{ Field } & \multirow{2}{*}{ Treatment } & \multicolumn{2}{c|}{$\begin{array}{c}\text { Plant height } \\
(\mathrm{cm})\end{array}$} & \multicolumn{2}{c}{ Effective tillers/hill } \\
\cline { 3 - 6 } & & 1999 & 2000 & 1999 & 2000 \\
\hline Uncontaminated & Fresh water & $73.2 \mathrm{a}$ & $72.2 \mathrm{a}$ & $11.8 \mathrm{a}$ & $12.0 \mathrm{a}$ \\
& Mixed water & $68.7 \mathrm{~b}$ & $69.1 \mathrm{a}$ & 9.11 & $9.2 \mathrm{~b}$ \\
& Industrial effluent & $63.8 \mathrm{c}$ & $64.7 \mathrm{~b}$ & $6.2 \mathrm{c}$ & $6.2 \mathrm{c}$ \\
\hline Contaminated & FV (\%) & 2.90 & 2.80 & 5.20 & 4.50 \\
& Fresh water & $72.0 \mathrm{a}$ & $72.7 \mathrm{a}$ & $4.3 \mathrm{a}$ & $4.3 \mathrm{a}$ \\
& Mixed water & $66.9 \mathrm{~b}$ & $66.0 \mathrm{~b}$ & $3.1 \mathrm{~b}$ & $3.2 \mathrm{~b}$ \\
& Industrial effluent & $62.1 \mathrm{c}$ & $61.3 \mathrm{c}$ & $2.1 \mathrm{c}$ & $2 . \mathrm{Ic}$ \\
\hline & $\mathrm{CV}(\%)$ & 1.00 & 0.70 & 6.70 & 6.10 \\
\hline
\end{tabular}

On the contrary, effluent of textile industry used for irrigation contained $\mathrm{Cu}$, $\mathrm{Mn}, \mathrm{C} 1$, and $\mathrm{Cr}$ beyond the maximum permissible limit (MPA). These elements particularly $\mathrm{Cr}$ might have exerted toxic effects on rice plants leading to decrease plant height and effective tillers per hill (Yamaguchi and Aso, 1977).

Textile industrial waste water exerted significant negative influence on the number of filled grains per panicle and 1000-grain weight of Boro rice in both uncontaminated and contaminated soil (Table 3). In both the seasons, the fresh soil showed the maximum number of filled grains/panicle and 1000-grain weight followed by mixed water and the minimum number of filled grains per panicle and 1000-grain weight were obtained by using polluted water for irrigation. Similarly in contaminated soil, the maximum number of filled grains per panicle, 
and 1000-grain weight were obtained by using fresh water as irrigation followed by mixed water, and minimum number of filled grains per panicle, and 1000grain weight was obtained due to polluted water used for irrigation (Table 3).

Table 3. The effect of waste water of textile industries on number of filled grains panicle' and 1000 grain weight of rice (BRRI dhan 29).

\begin{tabular}{l|l|c|c|c|c}
\hline \multirow{2}{*}{ Field } & \multirow{2}{*}{ Treatment } & \multicolumn{2}{c|}{$\begin{array}{c}\text { No. of filled grains/ } \\
\text { panicle }\end{array}$} & \multicolumn{2}{c}{1000 -grain wt (g) } \\
\cline { 3 - 6 } & & 1999 & 2000 & 1999 & 2000 \\
\hline \multirow{2}{*}{ Uncontaminated } & Fresh water & $146.7 \mathrm{a}$ & $148.4 \mathrm{a}$ & $25.7 \mathrm{a}$ & $25.4 \mathrm{a}$ \\
& Mixed water & $111.5 \mathrm{~b}$ & $111 . \mathrm{b}$ & $24.6 \mathrm{~b}$ & $24.1 \mathrm{~b}$ \\
& Industrial effluent & $75.4 \mathrm{c}$ & $78.3 \mathrm{c}$ & $22.9 \mathrm{c}$ & $22.4 \mathrm{c}$ \\
\hline Contaminated & FV (\%) & 7.0 & 6.20 & 1.90 & 1.30 \\
& Fresh water & $52.1 \mathrm{a}$ & $54.8 \mathrm{a}$ & $23.1 \mathrm{a}$ & $22.4 \mathrm{a}$ \\
& Mixed water & $28.9 \mathrm{~b}$ & $31.4 \mathrm{~b}$ & $22.3 \mathrm{a}$ & $21.4 \mathrm{~b}$ \\
& Industrial effluent & $20.2 \mathrm{c}$ & $21.9 \mathrm{c}$ & $20.0 \mathrm{~b}$ & $19.1 \mathrm{c}$ \\
\hline & $\mathrm{CV}(\%)$ & 12.50 & 9.30 & 3.60 & 2.60 \\
\hline
\end{tabular}

\section{Grain yield}

Fresh water gave the highest grain yield (5.23 t/ha in 1999 and $5.40 \mathrm{t} / \mathrm{ha}$ in 2000) followed by mixed water (4.19 t/ha in 1999 and $4.24 \mathrm{t} / \mathrm{ha}$ in 2000). The lowest grain yield (2.89 t/ha in 1999 and $2.91 \mathrm{t} / \mathrm{ha}$ in 2000) was obtained from polluted water used for irrigation (Table 4). Similarly in polluted soil, fresh water displayed the highest grain yield (2.49 t/ha in 1999 and $2.23 \mathrm{t} / \mathrm{ha}$ in 2000), followed by mixed water (1.86 t/ha in 1999 and $1.82 \mathrm{t} / \mathrm{ha}$ in 2000). The lowest grain yield (1.24 t/ha in 1999 and $1.16 \mathrm{t} / \mathrm{ha}$ in 2000) was obtained from polluted water (Table 4). Results revealed that fresh water irrigation always gave the highest yield, even in the polluted soil compared to polluted water. On the contrary, polluted water had negative influence on grain yield of rice and displayed significantly lowest grain yield. The grain yield reduction due to mixed and polluted water irrigations varied from 19.88 to $76.29 \%$ in the year 1998 and 21.48 to $78.52 \%$ in the year 1999 . The highest grain yield reduction over fresh water irrigation of 76.29 and $78.52 \%$ was observed in the year 1999 and 2000, respectively, in polluted soil irrigated with polluted water in comparison to fresh soil irrigated with fresh water. Markedly reduced grain yield with textile industrial waste water irrigation in both fresh and polluted soils was remarkable since this water had contained high concentration of toxic elements like $\mathrm{Cu}, \mathrm{Mn}$, $\mathrm{Cl}$, and $\mathrm{Cr}$. These elements particularly $\mathrm{Cr}$ might have exerted toxic effects to rice plants leading to decrease root elongation (Yamaguchi and Aso, 1977), decreased net photosynthesis (Austenfeld, 1979) and hampered physiological 
function in rice plants leading to reduced plant height, reduced number of effective tillers per hill, and very poor straw yield and ultimately resulted in drastic reduction of grain yield.

\section{Straw yield}

Fresh and polluted water had significant effect on straw yield of boro rice in both fresh and polluted soils (Table 4). In fresh soil, the highest straw yield (5.42 t/ha in 1999 and $5.57 \mathrm{t} / \mathrm{ha}$ in 2000) was recorded from fresh water as irrigation followed by mixed water (4.34 t/ha in 1999 and $4.40 \mathrm{t} / \mathrm{ha}$ in 2000). The lowest straw yield (3.02 t/ha in 1999 and $3.13 \mathrm{t} /$ ha in 2000) was recorded with polluted irrigation water. Similarly in polluted soil, highest straw yield $(2.59 \mathrm{t} / \mathrm{ha}$ in 1999 and $2.68 \mathrm{t} / \mathrm{ha}$ in 2000) was found from fresh water as irrigation followed by mixed water (2.01 t/ha in 1999 and $2.07 \mathrm{t} / \mathrm{ha}$ in 2000). The polluted water recorded the lowest straw yield (1.36 t/ha in 1999 and $1.40 \mathrm{t} / \mathrm{ha}$ in 2000). Results clearly indicate that textile industrial waste water was detrimental to rice growth and always gave the poor straw yield of boro rice even in the fresh soil. Fresh and textile waste water had significant effect on grain yield (Table 4) of boro rice in both fresh and polluted soils. This finding again agrees with the findings of Yagdi et al. (2000) where they observed that toxicity of heavy metals ( $\mathrm{As}, \mathrm{Cu}$, $\mathrm{Hg}, \mathrm{Zn}, \mathrm{Cd}, \mathrm{Cr}, \mathrm{Pb}, \mathrm{Mo}, \mathrm{Ni}$, and $\mathrm{Se}$ ) decreased plant growth and development.

Table 4. The effect of waste water of textile industries on grain and straw yield of rice (BRRIdhan 29).

\begin{tabular}{l|l|c|c|c|c}
\hline \multirow{2}{*}{ Field } & \multirow{2}{*}{ Treatment } & \multicolumn{2}{c|}{$\begin{array}{c}\text { Grain yield } \\
\text { (t/ha) }\end{array}$} & \multicolumn{2}{c}{$\begin{array}{c}\text { Straw yield } \\
\text { (t/ha) }\end{array}$} \\
\cline { 3 - 6 } & & 1999 & 2000 & 1999 & 2000 \\
\hline Uncontaminated & Fresh water & $5.23 \mathrm{a}$ & $5.40 \mathrm{a}$ & $5.42 \mathrm{a}$ & $5.57 \mathrm{a}$ \\
& Mixed water & $4.19 \mathrm{~b}$ & $4.24 \mathrm{~b}$ & $4.34 \mathrm{~b}$ & $4.40 \mathrm{~b}$ \\
& Industrial effluent & $2.89 \mathrm{c}$ & $2.91 \mathrm{c}$ & $3.02 \mathrm{c}$ & $3.13 \mathrm{c}$ \\
\hline Contaminated & CV (\%) & 6.90 & 4.30 & 3.30 & 2.00 \\
& Fresh water & $2.49 \mathrm{a}$ & $2.23 \mathrm{a}$ & $2.59 \mathrm{a}$ & $2.68 \mathrm{a}$ \\
& Mixed water & $1.86 \mathrm{~b}$ & $1.82 \mathrm{~b}$ & $2.0 \mathrm{lb}$ & $2.07 \mathrm{~b}$ \\
& Industrial effluent & $1.24 \mathrm{c}$ & $1.16 \mathrm{c}$ & $1.36 \mathrm{c}$ & $1.40 \mathrm{c}$ \\
\hline & $\mathrm{CV}(\%)$ & 8.50 & 6.30 & 5.70 & 5.10 \\
\hline
\end{tabular}

\section{Effects of industrial effluent}

Plants (rice) samples were collected at different growth stages in 1999-2000 from the experimental fields of the Rahim Textiles Industrial site, Mouchak. The toxic effects of waste water in comparison with fresh water on some nutrients were studied. 


\section{Nitrogen content}

Average $\mathrm{N}$ content at the different stages of the crop (tillering, flowering, and harvesting) as affected by various water treatments has been presented in Table 5. Different sources of irrigation water had significant influence on the $\mathrm{N}$ content of rice. The effluents from the textile industries were enriched with organic wastes and contained higher amounts of N, P, and K (Table 5). The decrease in N content of the crop as observed with waste water irrigation might be due to the presence of higher amount of $\mathrm{Pb}$ in the textile industries effluent (Table 6). The present study agreed well with the findings of Strand et al. (1990), Dahiya et al. (1990), and Osawa and Tazuke (1990). They also reported decreased N content with increasing $\mathrm{Cu}$ application and opined that $\mathrm{N}$ and $\mathrm{Cu}$ had antagonistic effect on each other. In this study, polluted water used for irrigation contained $\mathrm{Pb}$ and $\mathrm{Cu}$ above the permissible limit, which probably reduced the $\mathrm{N}$ content of rice grown with polluted water.

\section{Phosphorus and potassium content}

At different stages of rice, the $\mathrm{P}$ and $\mathrm{K}$ content were significantly affected by different qualities of irrigation water. In the tillering stage, the $\mathrm{P}$ and $\mathrm{K}$ concentration ranged from 0.03 to 0.10 and 0.16 to $0.48 \%$, respectively, at Mauchak (Table 5). The maximum amount of $\mathrm{P}(0.10 \%)$ and $\mathrm{K}(0.48 \%)$ was found in $\mathrm{T}_{1}$ treatment receiving fresh water irrigation. The minimum $\mathrm{P}$ content $(0.03 \%)$ and $\mathrm{K}(0.16 \%)$ was recorded in $\mathrm{T}_{6}$ treatment that received waste water of textile industries. At the flowering stage, $\mathrm{P}(0.04$ to 0.14$)$ and $\mathrm{K}$ concentration ranged from 0.23 to $1.06 \%$ (Table 5 ). The fresh water irrigation $\left(\mathrm{T}_{1}\right)$ showed the highest value of $\mathrm{P}(0.14 \%)$ and $\mathrm{K}(1.06 \%)$, while waste water irrigation $\left(\mathrm{T}_{6}\right)$ showed the lowest value $(0.04 \%)$ and $(0.16 \%)$, respectively. At the harvesting stage, $\mathrm{P}$ and $\mathrm{K}$ concentrations ranged from 0.06 to 0.18 and 0.33 to $1.22 \%$ respectively. The maximum concentration of $\mathrm{P}(0.18 \%)$ and $\mathrm{K}(1.22 \%)$ were obtained in $\mathrm{T}_{1}$ treatment and the minimum $\mathrm{P}(0.06 \%)$ and $\mathrm{K}(0.33 \%)$ in $\mathrm{T}_{6}$ treated plots. Phosphorus and potassium contents of rice were found to decrease depending on the concentration of effluents. The decrease in phosphorous and potassium contents of the crop might be attributed to the presence of higher amount of $\mathrm{Pb}, \mathrm{Zn}$, and $\mathrm{Cu}$ in the effluents that have antagonistic relationship with

$\mathrm{P}$ and K (Muchrimsyah and Mercado, 1990). Our results are in agreement with the findings of Khan and Khan (1983) who reported that the increasing $\mathrm{Pb}$ concentration had an adverse impact on $\mathrm{P}$ and $\mathrm{K}$ uptake by rice plant.

\section{Sulphur and zinc content}

The industrial waste water had significant effects on sulphur and zinc contents of rice (Table 5) at three growth stages (tillering, flowering, and harvesting 
stage).The maximum concentration of sulphur $(0.12,0.26,0.46 \%)$ in $\mathrm{T}_{1}$ and minimum $(0.03,0.05$, and $0.13 \%)$ was obtained in $\mathrm{T}_{6}$ treatment at three growth stages (tillering, flowering, and harvesting stage). The minimum $\mathrm{S}$ concentration during the flowering stage was noticed $(0.26 \%)$ in $\mathrm{T}_{6}$ treatment for higher concentration of $\mathrm{Zn}, \mathrm{Cu}, \mathrm{Fe}, \mathrm{Mn}, \mathrm{Cd}$, and $\mathrm{Pb}$ in waste water at Mouchak where effluent of textile industry was used (Table 5). In case of zinc content, the reverse trend was observed among the treatments at different growth stages. The maximum $\mathrm{Zn}$ content of the soil was recorded in the plots where industrial effluent was applied and the soil was also polluted as compared to the fresh water irrigated plots having uncontaminated soil. Waste water of textile industries resulted in higher $\mathrm{Zn}$ content by the crop (Table 5). The reason might be due to the higher $\mathrm{Zn}$ concentration in the waste water. Tripathi et al. (1988) also reported raw sewage irrigation increased $\mathrm{S}$ and $\mathrm{Zn}$ content in the soil.

\section{Magnesium and iron content}

The magnesium and iron absorption in rice straw at three stages of growth (e.g. tillering, flowering, and harvesting) as influenced by different treatments have been presented in Table 6. At the tillering stage, the $\mathrm{Mg}$ and Fe concentrations in rice straw were found (ranged from 70 to $180 \mathrm{ppm}$ and 40 to $260 \mathrm{ppm}$ at tillering, 50 to 290 and 90 to $270 \mathrm{ppm}$ at flowering, and 110 to $29 \& 60$ to $320 \mathrm{ppm}$ at harvesting) due to the application of effluent textile industry. The maximum concentration was noticed in $\mathrm{T}_{6}$ treatment, while minimum in $\mathrm{T}_{1}$ treatment at all the growing stages. The $\mathrm{Mg}$ and $\mathrm{Fe}$ concentration, of the treatments increased significantly from $T_{1}$ to $T_{6}$ treatment. The $T_{6}$ treatment contained maximum amount of $\mathrm{Mg}$ and $\mathrm{Fe}$ than rest of the treatments due to higher concentration of $\mathrm{Mg}$ and $\mathrm{Fe}$ in the waste water. The $\mathrm{Mg}$ concentration increased significantly with the concentration of waste water of the textile industry. Lee and Kim (1991) reported increased concentration and uptake of $\mathrm{Mg}$ and $\mathrm{Fe}$ by rice due to the use of waste water that supports our results.

\section{Copper and manganese content}

The $\mathrm{Cu}$ and $\mathrm{Mn}$ contents of rice crop at different stages of growth as affected by various industrial waste water are presented in Table 6. Data of six treatment levels showed that $\mathrm{Cu}$ and $\mathrm{Mn}$ content at different stages of rice increased significantly with the concentration of waste water. Copper and $\mathrm{Mn}$ concentration was highest in $\mathrm{T}_{6}$ and lowest in $\mathrm{T}_{1}$ treatment at all stages of growth of rice. The $\mathrm{Cu}$ and $\mathrm{Mn}$ concentration of the treatments increased significantly from $\mathrm{T}_{1}$ to $\mathrm{T}_{6}$ treatment. The $\mathrm{T}_{6}$ treatment contained maximum amount of $\mathrm{Cu}$ and $\mathrm{Mn}$ due to higher concentration in the waste water. The increase in $\mathrm{Cu}$ and $\mathrm{Mn}$ content in rice crop at all levels of treatment correlates with the findings of Khalid and Tinsley (1980). 
Table 5. The effect of effluent of industries on N, P, K, S, and Mg content at different growth stages of rice at Mouchak.

\begin{tabular}{|c|c|c|c|c|c|c|c|c|c|c|c|c|c|c|c|}
\hline \multirow{4}{*}{ Treat. } & \multicolumn{15}{|c|}{$\mathrm{N}, \mathrm{P}, \mathrm{K}, \mathrm{S}$, and $\mathrm{Zn}$ contents of rice at different growth stages } \\
\hline & \multicolumn{3}{|c|}{$\mathrm{N}(\%)$} & \multicolumn{3}{|c|}{$\mathrm{P}(\%)$} & \multicolumn{3}{|c|}{$\mathrm{K}(\%)$} & \multicolumn{3}{|c|}{$\mathrm{S}(\%)$} & \multicolumn{3}{|c|}{$\mathrm{Zn}(\mathrm{ppm})$} \\
\hline & \multicolumn{15}{|c|}{ Growth stages } \\
\hline & Tiller & Flower & Har. & Tiller & Flower & Har. & Tiller & Flower & Har. & Tiller & Flower & Har & Tiller & Flower & Har. \\
\hline $\mathrm{T}_{1}$ & 0.82 & 0.95 & 1.14 & 0.10 & 0.14 & 0.18 & 0.48 & 1.06 & 1.22 & 0.12 & 0.26 & 0.46 & 20 & 20 & 40 \\
\hline $\mathrm{T}_{2}$ & 0.77 & 0.82 & 0.86 & 0.08 & 0.11 & 0.14 & 0.33 & 0.83 & 0.96 & 0.11 & 0.20 & 0.39 & 30 & 40 & 50 \\
\hline $\mathrm{T}_{3}$ & 0.58 & 0.69 & 0.78 & 0.07 & 0.10 & 0.13 & 0.28 & 0.72 & 0.81 & 0.09 & 0.14 & 0.32 & 40 & 60 & 70 \\
\hline $\mathrm{T}_{4}$ & 0.46 & 0.60 & 0.64 & 0.05 & 0.08 & 0.11 & 0.22 & .0 .54 & 0.70 & 0.06 & 0.11 & 0.24 & 70 & 80 & 80 \\
\hline $\mathrm{T}_{5}$ & 0.38 & 0.42 & 0.56 & 0.04 & 0.06 & 0.08 & 0.18 & 0.46 & 0.55 & 0.05 & 0.07 & 0.17 & 70 & 80 & 100 \\
\hline $\mathrm{T}_{6}$ & 0.20 & 0.26 & 0.48 & 0.03 & 0.04 & 0.06 & 0.16 & 0.23 & 0.37 & 0.03 & 0.05 & 0.13 & 110 & 110 & 140 \\
\hline $\mathrm{CV}(\%)$ & 3.67 & 3.10 & 3.90 & 3.50 & 3.60 & 3.30 & 3.50 & 3.90 & 3.70 & 3.23 & 3.57 & 3.52 & 3.12 & 3.39 & 3.89 \\
\hline $\operatorname{LSD}\left({ }_{0.05 \%}\right)$ & 0.017 & 0.017 & 0.026 & 0.019 & 0.029 & 0.036 & 0.089 & 0.023 & 0.025 & 0.023 & 0.045 & 0.085 & 17 & 21 & 28 \\
\hline
\end{tabular}


Table 6. The effect of effluent of industries on $\mathrm{Zn}, \mathrm{Fe}, \mathrm{Cu}, \mathrm{Mn}$, and $\mathrm{Pb}$ content at different growth stages of rice at Mouchak.

\begin{tabular}{|c|c|c|c|c|c|c|c|c|c|c|c|c|c|c|c|}
\hline \multirow{4}{*}{ Treat. } & \multicolumn{15}{|c|}{$\mathrm{Mg}, \mathrm{Fe}, \mathrm{Cu}, \mathrm{Mn}$ and $\mathrm{Pb}$ contents of rice at different growth stages } \\
\hline & \multicolumn{3}{|c|}{$\operatorname{Mg}(\%)$} & \multicolumn{3}{|c|}{$\mathrm{Fe}(\%)$} & \multicolumn{3}{|c|}{$\mathrm{Cu}(\mathrm{ppm})$} & \multicolumn{3}{|c|}{$\mathrm{Mn}(\mathrm{ppm})$} & \multicolumn{3}{|c|}{$\mathrm{Pb}(\mathrm{ppm})$} \\
\hline & \multicolumn{15}{|c|}{ Growth stages } \\
\hline & Tiller & Flower & Har. & Tiller & Flower & Har. & Tiller & Flower & Har. & Tiller & Flower & Har & Tiller & Flower & Har. \\
\hline $\mathrm{T}_{1}$ & 0.007 & 0.009 & 0.011 & 40 & 50 & 60 & 20 & 40 & 60 & 40 & 80 & 180 & 10 & 20 & 30 \\
\hline $\mathrm{T}_{2}$ & 0.010 & 0.013 & 0.014 & 70 & 80 & 90 & 80 & 90 & 110 & 90 & 180 & 260 & 20 & 30 & 40 \\
\hline $\mathrm{T}_{3}$ & 0.012 & 0.018 & 0.019 & 130 & 170 & 160 & 130 & 150 & 160 & 160 & 220 & 350 & 40 & 50 & 50 \\
\hline $\mathrm{T}_{4}$ & 0.014 & 0.021 & 0.023 & 150 & 210 & 220 & 160 & 210 & 220 & 210 & 300 & 460 & 50 & 60 & 70 \\
\hline $\mathrm{T}_{5}$ & 0.016 & 0.023 & 0.027 & 210 & 250 & 290 & 230 & 280 & 290 & 360 & 480 & 620 & 60 & 60 & 80 \\
\hline $\mathrm{T}_{6}$ & 0.018 & 0.027 & 0.029 & 260 & 290 & 320 & 290 & 320 & 350 & 540 & 70 & 810 & 70 & 70 & 100 \\
\hline $\mathrm{CV}(\%)$ & 3.17 & 3.83 & 3.37 & 3.61 & 3.77 & 3.86 & 3.11 & 3.88 & 3.09 & 3.38 & 3.72 & 3.51 & 3.79 & 3.44 & 3.29 \\
\hline $\operatorname{LSD}(0.05 \%)$ & 0.0037 & 0.0066 & 0.0064 & 45 & 58 & 7 & 42 & 63 & 64 & 70 & 110 & 140 & 13 & 15 & 17 \\
\hline
\end{tabular}

Note: Har. = Harvesting period. 


\section{Lead content}

The accumulation of lead $(\mathrm{Pb})$ in rice at different stages of growth as affected by various quality of water is presented in Table 6 . At the tillering stage, the $\mathrm{Pb}$ concentration in rice ranged from 10 to $70 \mathrm{ppm}$. The maximum $\mathrm{Pb}$ concentration was noticed in $T_{6}(70 \mathrm{ppm})$ treatment, while the minimum in $T_{1}(10 \mathrm{ppm})$ treatment where textile industry effluent was used. The $\mathrm{Pb}$ concentration of the treatments increased significantly from $T_{1}$ to $T_{6}$ treatment. The $T_{6}$ treatment contained maximum amount of $\mathrm{Pb}$ than rest of the treatments due to higher concentration of $\mathrm{Pb}$ in the waste water. Same result was found at the flowering stage. In case of harvesting stage, the concentration of lead ranged from 30 to $100 \mathrm{ppm}$ at Textile industry of Mouchak area. The $\mathrm{Pb}$ content of the crop was found to increase due to the application of waste water. All the waste water except fresh water treatment resulted in higher $\mathrm{Pb}$ content by the rice in Mouchak. Chen et al. (1991) noticed that waste water that contained $\mathrm{Pb}$ might influence lead content in rice crops.

\section{Nutrient Uptake of Rice}

The uptakes of N, P, K, S, and Zn by rice in Mouchak as affected by different qualities of water were studied at harvest and the data are presented in Table 7.

\section{Nitrogen, phosphorus, and potassium}

The maximum N, P, and $\mathrm{K}$ uptake of rice crop (123.23, 19.46, and 133.81 per $\mathrm{kg}$ ) was observed in the fresh soil irrigated with fresh water and minimum values of $12.38,1.55$, and $9.55 \mathrm{~kg} / \mathrm{ha}$, in the polluted soil irrigated with polluted water at Mouchak (Table 7). Fresh soil and fresh water always gave significantly higher uptake of $\mathrm{N}$. The maximum decrease in $\mathrm{N}, \mathrm{P}$, and $\mathrm{K}$ uptake of the crop was recorded in the plots where textile industrial waste water was applied. The lowest and very poor uptake of $\mathrm{N}, \mathrm{P}$, and $\mathrm{K}$ with polluted water in industrially polluted soil was likely, since polluted water and soil contained toxic level of heavy metals like $\mathrm{Zn}, \mathrm{Cu}, \mathrm{Mn}, \mathrm{Cd}$, and $\mathrm{Pb}$ which depressed the yield significantly. It is to be noted here that nutrient uptake is the function of biomass yield and nutrient concentration in plant. As the yield decreased significantly in polluted soil irrigated with polluted water, $\mathrm{N}$ uptake also reduced significantly. This finding is in agreement with the findings of Yagdi et al. (2000) and Lee and Kim, 1991) who reported decreased uptake of N, P, and $\mathrm{K}$ with polluted water. 
Table 7. The effect of effluent of textile industries on nutrient uptake by rice at Mouchak.

\begin{tabular}{l|l|l|l|l|l}
\hline \multirow{2}{*}{ Treatment } & \multicolumn{5}{c}{ Nutrient uptake (kg/ha) } \\
\cline { 2 - 6 } & \multicolumn{2}{|c}{$\mathrm{N}$} & \multicolumn{2}{c}{$\mathrm{P}$} & \multicolumn{2}{c}{$\mathrm{K}$} & $\mathrm{S}$ & $\mathrm{Zn}$ \\
\hline $\mathrm{T}_{1}$ & 123.23 & 19.46 & 133.81 & 43.24 & 0.43 \\
$\mathrm{~T}_{2}$ & 73.87 & 12.03 & 82.46 & 26.63 & 0.43 \\
$\mathrm{~T}_{3}$ & 46.64 & 7.77 & 48.44 & 14.35 & 0.42 \\
$\mathrm{~T}_{4}$ & 31.94 & 5.49 & 27.45 & 9.98 & 0.40 \\
$\mathrm{~T}_{5}$ & 19.90 & 3.18 & 21.89 & 6.37 & 0.40 \\
$\mathrm{~T}_{6}$ & 12.38 & 1.55 & 9.55 & 2.84 & 0.36 \\
\hline CV $(\%)$ & 1.92 & 3.68 & 1.46 & 3.24 & 7.90 \\
LSD $(0.05 \%)$ & 1.8 & 0.56 & 1.43 & 1.02 & 0.06 \\
\hline
\end{tabular}

\section{Sulphur and zinc}

Different qualities of soil and water exerted significant influence on the uptake of $\mathrm{S}$ and $\mathrm{Zn}$ by rice (Table 7). The $\mathrm{S}$ and $\mathrm{Zn}$ uptake varied from 2.84 to 43.24 and 0.36 to $0.43 \mathrm{~kg} / \mathrm{ha}$, respectively, at Mouchak. The highest $\mathrm{S}(43.24 \mathrm{~kg} / \mathrm{ha}$, and $\mathrm{Zn}$ $(0.43 \mathrm{~kg} / \mathrm{ha}$, uptake was recorded in fresh soil with fresh water and the lowest were obtained in polluted soil with polluted water. The results also showed that between the two polluted soil and water used, the textile waste water depressed more the uptake of $\mathrm{Zn}$ than S. The increase in $\mathrm{Zn}$ uptake in rice crop at all levels of treatment are correlated with the findings of Khalid and Tinsley (1980) and Yagdi et al. (2000).

\section{Conclusion}

This study indicates that textile waste water was rich in nutrients but loaded with different heavy metals beyond the permissible limit. Heavy metal had antagonistic effects on essential plant nutrient uptake. Plant did not uptake adequate amount of nutrients from waste water, which was on the growth and yield of rice. Untreated industrial effluent can pollute the receiving water bodies and affect crop production, aquatic life and ultimately produces negative impact on human health. Therefore, industrial effluent should be planned to discharge and or recycled before going to the water bodies.

\section{References}

Austenfeld, F.A. 1979. The effect of Ni, Co, and Cr on net photosynthesis of primary and secondary leaves of Phaseolus vulgaris L. Photosynthetica 13: 434-438.

Breekle, S.W. and H. Kahle. 1992. Effect of toxic heavy metals $(\mathrm{Cd}, \mathrm{Pb})$ on the growth and mineral nutrition of bean (Fagus sylvatical). Vegetatio 101: 43-53. 
Chen, H.M., C.R. Zheng and X. H. Sun. 1991. Effects of different Pb compounds on growth and heavy metal uptake of wetland rice. Pedosphere 1(3): pp.553-264.

Dahiya, D. J., S. Mahendra, R.P. Narwal, J.P. Singh and M. Singh. 1990. Effect of chloride and sulphate of copper on salinity, $\mathrm{pH}$ and nitrogen mineralization of soil during growing of wheat. J. Indian Soc. Soil Sci., 38(3). pp. 555-557.

Hellawell, J.M. 1986. Biological indicators of fresh water pollution and environmental management, Elsvier Applied Science Publisher, London.

Khalid, B.Y. and J. Tinsely. 1980. Some effects of heavy metal toxicity on Rye grass. Plant and Soil. 55: 139-144.

Khan, S. and N. Khan. 1983. Influence of lead and cadmium on the growth and nutrient concentration of tomato and eggplant. Plant and Soil. 74: 287-394.

Lee, S.J. and J.E. Kim. 1991. Pollution of $\mathrm{Pb}$ in paddy field soil and rice plants at road side areas. Korean Env. Agriculture. 10: 138-148.

Muchrimsyah, E.H. and B.T. Mercado. 1990. Lead-phosphate interaction in the germination and vegetative growth of two rice varieties. Philippine Agriculturist. 73: 207-2 19.

Osawa, T., and A. Tajuke. 1990. The effect of form of nitrogen supplied and $\mathrm{pH}$ level of the nutrient solution on copper toxicities in vegetative crops. J. Japanese Soc. Hort.Sci., 59(3): 519-525.

Steel, R. C. B. and J.H. Torii. 1960. Principles and procedures of statistics, McGraw Hall Book, New York. U. S. A. pp. 377-398.

Strand, V., B.N. Zolotareva and A.J. Lisovskij. 1990. Effect of Pb, Cd, and Cu content in the soil on their accumulation and yield of crops. Rostlinna-Vyroba 36(4): 411-417.

Tripathi, B.D., D. Kumari and R.K. Dwivedi. 1988. Effect of sewage irrigation on soil properties and yield of potato (Solanum tuberosum). Geo-Eco-Trop, India. 12(1-4): 133-141.

Yagdi, K., 0. Kacar and N. Azkar. 2000. Heavy metals concentration in agriculture. "Toprakiardeki agir metal Kirligi ye taninsal etikileri ondokuz Mayis Universitasi, Ziraat Fahultasi Dergisi 15(2): 109-115.

Yamaguchi, T., and S. Aso. 1977. Chromium from the stand point of plant nutrition: I. Effect of Cr, concentration on the germination and growth of plants. J. Sci. Soil Manure, 29(48): 466-470. 